Niniejsza publikacja jest dostęna na licencji Creative Commons. Uznanie autorstwa-Użycie niekomercyjne-Bez utworów zależnych 3.0 Polska. Pewne prawa zastrzė̇one na rzecz autora. Zezwala się na wykorzystanie publikacji zgodnie z licencja - pod warunkiem zachowania niniejszej informacji licencyjnej oraz wskazania autora jako właściciela praw do tekstu. Treść licencji jest dostępna na stronie: http:/ / creativecommons.org/licenses/ by-nc-nd/ 3.0/pl/

Lingwistyka Stosowana 23: 3/ 2017, 151-165

\author{
Jolanta LĄCKA-BADURA
}

Uniwersytet Ekonomiczny w Katowicach

\title{
Ocena wiedzy i kompetencji przedmiotowych jako element dydaktyki języka obcego dla celów biznesowych w programie studiów wyższych
}

\begin{abstract}
:
Assessment of specific purpose knowledge and competence as an element of Business English pedagogy at the tertiary level

The paper is motivated by the widely held view that LSP pedagogy should aim to develop students' dual competence, encompassing - on the one hand - their linguistic knowledge and skills, and - on the other - their professional competence including (elements of) specialist content knowledge and the skills necessary to effectively communicate in specific purpose settings. Consequently, assessment in LSP pedagogy should take into account not only students' linguistic competence, but also measure their ability to effectively and professionally perform communicative tasks typical of the target settings. The study examines how pre-experience undergraduate students at the University of Economics in Katowice perceive assessment of their professional communicative competence, including elements of specific purpose knowledge, by a Business English teacher. The findings suggest that the degree of acceptance for the assessment of dual competence in a university Business English course is very high; importantly, it increases with students' growing business awareness and content knowledge.
\end{abstract}

\section{Wstęp}

Jedną z nieodłącznych cech dydaktyki języków specjalistycznych (JS) jest wykorzystanie treści i rodzajów zadań typowych dla danej dziedziny. Rola treści fachowych w analizie i glottodydaktyce JS wynika z samych (dość zróżnicowanych) koncepcji i definicji języka specjalistycznego/ języka fachowego/ technolektu (zob. m.in. H. Basturkmen 2001, 2006; T. Dudley-Evans/ M. St John 1998; E. Gajewska/ M. Sowa 2014; S. Grucza 2007, 2008, 2009 T. Hutchinson/ A. Waters 1987; J. Lukszyn 2005; P. Sobkowiak 2008). Ogólnie przyjęte sposoby pojmowania kompetencji w zakresie komunikacji specjalistycznej również wskazują na doniosłą rolę kompetencji merytorycznej, opartej na fachowej wiedzy i doświadczeniu zawodowym. D. Douglas (2000) przyjmuje, że na kompetencję w zakresie języka specjalistycznego składają się następujące komponenty: wiedza i kompetencje językowe (gramatyczne, tekstualne, funkcjonalne i socjolingwistyczne), wiedza przedmiotowa oraz tzw. kompetencja strategiczna. Ta ostatnia pozwala na użycie wiedzy językowej i przedmiotowej w sposób adekwatny do sytuacji komunikacyjnej (por. S. Gru- 
cza 2006, 2007, 2009; M. Canale/ M. Swain 1980; M. Canale 1983). Choć badacze nie są $\mathrm{w}$ pełni zgodni co do tego, czy przekazywanie podstawowej wiedzy z danej dziedziny jest jednym z celów glottodydaktyki specjalistycznej (por. np. H. Basturkmen 2006 i S. Grucza 2007), ścisła integracja wiedzy merytorycznej i umiejętności językowych, ich wzajemne przenikanie się i oddziaływanie na różnych poziomach wydają się kwestią bezsporną (zob. V.K. Bhatia et al. 2011; P. Mamet 2002; J. Zhao 2002; W. Zhu 2008). Język i jego użycia są nierozerwalnie związane ze strukturami myślowymi danej dziedziny, metodami stosowanymi przez nią, stanem jej wiedzy i badań naukowych. Stopień tzw. socjalizacji fachowej wpływa zasadniczo na posługiwanie się językiem specjalistycznym (zob. B. Kubiak 2002; P. Strevens 1973).

Istotna rola fachowych treści przedmiotowych w glottodydaktyce jest cechą łączącą podejście LSP (Languages for Specific Purposes) z metodą określaną mianem Content-Based Instruction (CBI), polegającą na zintegrowanym (w różnym stopniu) nauczaniu języka i przedmiotu kierunkowego (zob. D.M. Brinton 2007, D.M. Brinton et al. 1989; S.B. Stryker/ B.L. Leaver 1997). W toku kursu opartego na założeniach CBI biegłość językowa osiągana jest pośrednio, poprzez naukę treści przedmiotu wykładanego w tym języku. Język jest tu zatem narzędziem służącym do przyswojenia treści przedmiotowych. Literatura dostarcza wielu przykładów łączenia obydwu podejść (CBI i LSP) na kursach języka specjalistycznego. Treści fachowe są często podstawowym wyznacznikiem organizacji kursów LSP, a ich regularne wykorzystywanie w dydaktyce przynosi wiele pozytywnych efektów (zob. E. Cianflone/ R. Coppolino 2009; W. Grabe/ F.L. Stoller 1997; G. Kavaliauskiene 2004; L.F. Kasper 1997; B. Kubiak 2005; P. Master 1997; J.C. Richards/ T.S. Rodgers 2002).

Podobnie jak koncepcje języka specjalistycznego i komunikacji specjalistycznej, również pojęcia 'język obcy dla celów biznesowych' i 'komunikacja w biznesie' nie zawsze są rozumiane w ten sam sposób (zob. np. F. Bargiela-Chiappini/ Z. Zhang 2013; M. Ellis/ C. Johnson 2000 E. Frendo 2005; B. Ligara/ W. Szupelak 2012; J. Łompieś 2008; D. Pickett 1986; P. Strevens 1977). Badacze wskazują na różnorodność nazewnictwa (m.in. język biznesu, język ekonomii, język biznesu i ekonomii, język obcy dla celów biznesowych) i niejednoznaczne definicje wynikające z nieostrych granic między pojęciami takimi jak biznes, ekonomia, gospodarka (zob. P. Szerszeń 2015; J. Zhao 2002), jak również z 'mieszanego' ('hybrydowego', 'quasiautonomicznego', 'quasi-specjalistycznego', 'otwartego') charakteru tzw. języka biznesu i komunikacji biznesowej (zob. M. Ellis/ C. Johnson 2000 E. Frendo 2005; M. Grygiel 2015; B. Kubiak 2006; B. Ligara/ W. Szupelak 2012; J. Łompieś 2008). Język biznesu i ekonomii może obejmować swym zakresem niezwykle szeroki zakres dyscyplin specjalistycznych, ma także większy niż inne języki specjalistyczne zakres wspólny z językiem ogólnym; komunikacja biznesowa z kolei może obejmować wysoce specyficzne lub bardzo różnorodne typy zadań i interakcji z udziałem nie tylko specjalistów/ profesjonalistów, ale także na linii specjalistaniespecjalista (np. klient). 
W niniejszym opracowaniu zastosowano pojęcie język biznesu (odpowiednik anglojęzycznego terminu Business English powszechnie stosowanego jako nazwa przedmiotu nauczanego w programie studiów wyższych), jednak rozumiane jest ono szeroko, jako język biznesu i ekonomii obejmujący język potrzebny - z jednej strony - aby rozumieć treści biznesowe i zjawiska ekonomiczne oraz móc o nich rozmawiać, a z drugiej strony - aby prowadzić biznes lub skutecznie sie komunikować i funkcjonować w biznesie (por. m.in. M. Nelson 2000; D. Pickett 1986; P. Strevens 1977). ${ }^{1}$ Glottodydaktyka języka biznesu powinna zatem umożliwiać kształtowanie tzw. 'podwójnej kompetencji', tzn. nie tylko kompetencji językowej, ale również szeroko rozumianej kompetencji zawodowej (uwzględniającej - obok samego języka - wiedzę merytoryczną, kompetencję komunikacyjną z jej aspektami pozajęzykowymi, interpersonalnymi i interkulturowymi) (por. S. Donna 2000; D. Douglas 2000; M. Ellis/ C. Johnson 2000; E. Frendo 2005; E. Gajewska/ M. Sowa 2014; J. Łompieś 2008).

$\mathrm{Na}$ kursach prowadzonych $\mathrm{w}$ firmach i instytucjach (tzw. wariant profesjonalny glottodydaktyki specjalistycznej - zob. B. Ligara/ W. Szupelak 2012) integracja treści językowych i fachowych następuje w sposób naturalny. Dzięki doświadczeniu zawodowemu i zdobytemu wcześniej wykształceniu, uczestnicy zazwyczaj posiadają odpowiednią wiedzę specjalistyczną, doskonale znają kontekst i kulturę organizacji oraz powszechnie stosowane praktyki komunikacyjne. W środowisku zawodowym ,język jest (...) na usługach profesji” (zob. E. Gajewska/ M. Sowa 2014: 208) - ma służyć skutecznej i profesjonalnej komunikacji, która z kolei umożliwia realizację określonych zadań i działań. Integracja ta nie jest już tak bezproblemowa na kursach języka specjalistycznego oferowanych w programie studiów wyższych (tzw. wariant dydaktyczny), skierowanych do osób nie tylko nie posiadających doświadczenia zawodowego, ale również będących na początkowym etapie przyswajania wiedzy przedmiotowej. Studenci doświadczają licznych problemów ze zrozumieniem nie tyle nowych jednostek leksykalnych, co raczej koncepcji, jakie kryją się pod tymi jednostkami; trudno im również odnieść owe koncepcje do poznanej wcześniej rzeczywistości (por. P. Sobkowiak 2008). Świadomość konwencji oraz przyjętych sposobów działań i zachowań komunikacyjnych, jak również strategii argumentacji powszechnie stosowanych w środowisku biznesowym, jest zazwyczaj niska lub bardzo niska, szczególnie wśród studentów pierwszego roku studiów licencjackich, co przekłada się na rażące błędy popełniane w trakcie ćwiczenia sprawności produktywnych. Trudnościom wynikającym z braku wiedzy fachowej oraz niskiej świadomości konwencji komunikacyjnych często towarzyszy ponadto bardzo słaba świadomość interkulturowa, tak istotna w kontaktach biznesowych. Wydaje się zatem nie tylko uzasadnione, ale nawet konieczne, aby sposób prowadzenia zajęć i dobór materiałów pozwalały na kształtowanie kompetencji językowej oraz kompetencji komunikacyjnej charakterystycznej dla świata biznesu, jak również umożliwiały studentom zrozumienie - przynajmniej w podstawowym zakresie - omawia-

${ }^{1}$ Por. również F. Pierini (2014), który szczegółowo omawia podobieństwa i różnice między Business English i English for Economics. 
nych na zajęciach językowych treści biznesowych, z którymi nie mieli dotąd styczności na innych (kierunkowych) przedmiotach. Język angielski nauczany dla celów biznesowych jest tu zatem nie tyle „na usługach profesji”, co na usługach procesu ksztaltowania i formowania przyszłych profesjonalistów.

W części pierwszej niniejszego artykułu przedstawiono (w skrótowy sposób) teoretyczne aspekty ewaluacji tzw. 'podwójnej kompetencji' w dydaktyce języków specjalistycznych. Część druga zawiera prezentację wyników badania mającego na celu ustalenie w jaki sposób studenci studiów licencjackich Uniwersytetu Ekonomicznego w Katowicach, nie posiadający doświadczenia zawodowego i będący na początkowym etapie przyswajania wiedzy specjalistycznej, postrzegają rolę wykładowcy Business English w rozwijaniu i ocenianiu nie tylko ich wiedzy i kompetencji językowych, ale także szeroko rozumianych 'kompetencji fachowych'. ${ }^{2}$

\section{Ewaluacja w dydaktyce języków specjalistycznych (w tym: języka biznesu)}

Ewaluacja w nauczaniu i uczeniu się języków obcych jest nierozerwalnie związana z pojęciem celów - jej głównym zadaniem jest sprawdzenie czy uczący się owe zamierzone cele osiągnęli (zob. D. Douglas 2000; E. Gajewska/ M. Sowa 2014). W dydaktyce języków specjalistycznych nastawienie na cel i zadania jest szczególnie istotne; kursy języka specjalistycznego planowane są dla konkretnych grup odbiorców o ściśle określonych potrzebach, stąd też cele muszą być jasno sprecyzowane (zob. H. Basturkmen 2001, 2006; T. Dudley-Evans/ M.J. St. John 1998; E. Gajewska/ M. Sowa 2014; T. Hutchinson/ A. Waters 1987; P. Sobkowiak 2008).

Badacze i praktycy JS podkreślają, że wspomniana we wstępie ,,podwójna kompetencja" uczestników kursów języków specjalistycznych (z jednej strony - kompetencja językowa, z drugiej - kompetencja zawodowa, zawierająca w sobie elementy kompetencji interkulturowej i wiedzy fachowej) powinna być uwzględniana zarówno w procesie uczenia języka specjalistycznego, jak i w fazie ewaluacji postępów w nauce (zob. D. Douglas 2000, 2013; D. Douglas/ R.K. Myers 2000; E. Gajewska/ M. Sowa 2014; P. Sobkowiak 2008). ${ }^{3}$ D. Douglas (2013) zauważa, że ewaluacja w nauczaniu języków specjalistycznych oparta jest na zasadach wynikających z głównych cech tych języków: zróżnicowanie użycia języka w różnych kontekstach, precyzyjność użycia fachowej terminologii i wymieniona powyżej interakcja

\footnotetext{
${ }^{2} \mathrm{~W}$ literaturze anglojęzycznej dotyczącej glottodydaktyki wyrażenia evaluation i assessment nie są przez wielu autorów uznawane jako synonimy; ewaluacja jest zazwyczaj pojmowana szerzej - oprócz oceny wiedzy i kompetencji uczących się obejmuje także ocenę programu nauczania i efektywności kursu (zob. np. D. Douglas 2000; T. Dudley-Evans/ M.J. St. John 1998; B.K. Lynch 2003; R. White et al. 1991). Jednak precyzyjne rozróżnienie polskojęzycznych pojęć takich jak ocena, ocenianie, ewaluacja nie wydaje się istotne dla niniejszego opracowania, dlatego też wyrażenia te będą używane jako synonimy odnoszące się do oceny wiedzy i kompetencji uczących się oraz ich postępów w nauce (por. T. Angelo/ K.P. Cross 1993; E. Gajewska/ M. Sowa 2014).

${ }^{3}$ Podejście takie jest spójne z założeniami oceny sprawności produktywnych przyjętymi w podejściu komunikacyjnym, na którym opiera się dydaktyka LSP (por. H. Komorowska 2005).
} 
pomiędzy językiem specjalistycznym i specjalistyczną/ profesjonalną wiedzą z danej dziedziny. Interakcja ta jest jednym z najważniejszych cech dystynktywnych ewaluacji w dydaktyce JS, gdzie elementy wiedzy fachowej uznawane są za integralną część umiejętności w zakresie języka specjalistycznego (zob. D. Douglas 2000; P. Mamet 2002). W dydaktyce języka nauczanego dla celów specjalistycznych ocenie powinna zatem podlegać poprawność nie tylko językowa, ale także - a często przede wszystkim - właściwe zrozumienie kontekstu zawodowego, trafność treści merytorycznych, adekwatność użytych środków językowych, stosowność strategii argumentacji i perswazji, ich zasadność i spójność, umiejętność precyzyjnego wyrażania się właściwego dla danej dziedziny - wszystkie te kryteria powinny być rozpatrywane jako składowe elementy oceny końcowego rezultatu zadania (zob. D. Douglas/ R.K. Myers 2000; E. Gajewska/ M. Sowa 2014). ${ }^{4}$ Krótko ujmuje te kryteria D. Douglas (2013): uczący się powinni wykazać co potrafią zrobić za pomocą języka, który przyswoili, oraz z jakim skutkiem są w stanie wykorzystać swoją wiedzę i kompetencję merytoryczną $\mathrm{w}$ celu wykonania zadania podobnego do autentycznych działań komunikacyjnych typowych dla danego środowiska zawodowego. Podobnie E. Gajewska i M. Sowa postulują ocenę „operatywnego użycia języka w kontekście zawodowym" (2014: 210). Autorki podkreślają konieczność dołożenia wszelkich starań, aby zadania ewaluacyjne wykorzystywane w glottodydaktyce specjalistycznej zawierały odniesienia do wiedzy zawodowej oraz były „zbieżne z logiką właściwą użyciu języka w obszarze zawodowym" (tamże).

Warto zauważyć, że w bardziej tradycyjnych modelach nauczania języka ogólnego wiedza merytoryczna często była uznawana za czynnik maskujący rzeczywiste umiejętności językowe uczących się i, w związku z tym, pomijana przy ocenie (zob. D. Douglas 2000; P. Sobkowiak 2008). Jednak w nowoczesnej dydaktyce JS język traktowany jest jako środek do nabycia wiedzy i kompetencji zawodowych oraz do efektywnego wykonywania zadań, dlatego też wyznaczanie granicy między wiedzą/ kompetencją językową i merytoryczną nie służy budowaniu profesjonalnych kompetencji komunikacyjnych (zob. D. Douglas 2013; S. Jacoby/ T. McNamara 1999).

Nie oznacza to, że ewaluacja podwójnej kompetencji w języku specjalistycznym przebiega bezproblemowo. Jednym z głównych warunków, jakie musza zostać spełnione, aby taka ewaluacja mogła być dokonana rzetelnie i profesjonalnie jest dostateczna wiedza i kompetencja merytoryczna wykładowcy; nauczyciel języka specjalistycznego, nie będąc ekspertem $\mathrm{w}$ danej dziedzinie, musi być przynajmniej zorientowany i zainteresowany treścią przedmiotu, posiadać umiejętność sprawnego łączenia nauczania komunikacji zorientowanej na przekaz treści i komunikacji zorientowanej na przekaz językowy, a także systematycznie poszerzać swoją wiedzę merytoryczną, specjalistyczną kompetencję komunikacyjną i interkulturową (zob. A. Cheng 2015; M. Ellis/ C. Johnson 2000 T. Dudley-Evans/ M. St John 1998; G. Fergusson 1997; E. Gajewska/ M. Sowa 2014; B. Kubiak 2005).

${ }^{4}$ Tzw. podejście zadaniowe (task-based learning) (zob. np. J. Willis 1996) uznawane jest za najwłaściwsze podejście do nauczania i oceniania w dydaktyce języka biznesu (JB) (zob. M. Ellis/ C. Johnson 2000; E. Frendo 2005; E. Gajewska/ A.M. Sendur 2015; B. Ligara/ W. Szupelak 2012). 


\section{Badanie ankietowe}

Celem badania było ustalenie w jaki sposób studenci studiów licencjackich (bez doświadczenia zawodowego, na początkowym etapie przyswajania wiedzy z dziedziny biznesu i ekonomii) postrzegają ocenianie uwzględniające nie tylko kompetencje językowe, ale także szeroko rozumiane 'kompetencje fachowe'.

W badaniu wzięło udział 236 studentów Uniwersytetu Ekonomicznego w Katowicach. W analizie uwzględniono 224 prawidłowo wypełnione anonimowe ankiety, z czego 118 wypełnili studenci I roku, a 106 - studenci II roku. Przed badaniem studenci otrzymali do wykonania $\mathrm{w}$ ramach pracy domowej zadanie polegające na napisaniu dokumentu o charakterze biznesowym (w zależności od grupy $\mathrm{i}$ etapu nauki: raport, email, notatka służbowa, list motywacyjny). ${ }^{5}$ Zadanie zostało poprzedzone instrukcją dotyczącą sposobu pisania danego typu dokumentu, analizą przykładów oraz ćwiczeniami. Zgodnie z zaleceniami w zakresie kontroli bieżącej (zob. np. H. Komorowska 2005), jak i z zasadami konstruowania i oceniania zadań ewaluacyjnych dla kursu języka specjalistycznego (D. Douglas 2000), ${ }^{6}$ nauczyciel w sposób jasny i precyzyjny określił cel zadania i najważniejsze kryteria oceny, informując studentów, że treść i stopień profesjonalizmu będą stanowiły co najmniej tak samo ważny element oceny, jak wykazane umiejętności i kompetencje językowe. ${ }^{7}$ Przed oddaniem prac nauczycielowi studenci mieli również możliwość dokonania

${ }^{5}$ Rozwijanie sprawność pisania, uznawanej w dydaktyce JB za bardziej istotną niż w dydaktyce języka ogólnego (JO) (zarówno z punktu widzenia komunikacji, jak i funkcji prawnej i dokumentacyjnej), rodzi różnorakie problemy nie tylko natury językowej, ale także problemy dotyczące efektywności komunikacji, budowania relacji interpersonalnej, kreowania profesjonalnego wizerunku (zob. B. Ligara/ W. Szupelak 2012). Wysoce intencjonalny charakter komunikacji w biznesie sprawia, że ,praktycznie każdy pisemny akt komunikacji jest jakiegoś rodzaju aktem mowy, którego celem jest kształtowanie rzeczywistości pozajęzykowej" (tamże: 154).

${ }^{6}$ Omawiając zasady konstruowania zadań ewaluacyjnych dla kursu języka specjalistycznego D. Douglas (2000: 50-74) postuluje następujące komponenty i kryteria:

1) instrukcja (rubric) - informacje dotyczące procedury zadania ewaluacyjnego (instrukcja wyjaśnia naturę zdarzenia komunikacyjnego, precyzuje jego cele, oczekiwaną formę i strukturę odpowiedzi, czas na wykonanie zadania oraz zasady oceny);

2) właściwe dane wejściowe (input) - dane dotyczące sytuacji komunikacyjnej (kontekstu), specjalistyczne treści, które uczący się będzie miał za zadanie przetworzyć w celu wykonania zadania - m.in. tło sytuacyjne, uczestnicy, cele, zawartość, język, normy interakcji;

3) oczekiwana odpowiedź (expected response) - precyzyjne określenie czego oczekuje się od uczącego się;

4) interakcja pomiędzy danymi wejściowymi a odpowiedzią (interaction between input and response) - kwestia reakcyjności (interakcja odwzajemniona/ nieodwzajemniona), zakresu danych wejściowych, jakie uczący się musi przetworzyć, stopień bezpośredniości relacji między treścią a oczekiwaną odpowiedzią;

5) kryteria oceny (assessment) - uwzględniające możliwość zaakceptowania uzyskanej odpowiedzi przez specjalistów w danej dziedzinie; kryteria poprawności (adekwatność pod względem długości, formy, treści, stylu, tonu, precyzja wypowiedzi, jasność, zwięzłość, stosowność środków argumentacji i perswazji, poprawność językowa), punktacja, skala ocen.

7 Waga szeroko rozumianych 'kompetencji fachowych' w nauce języka angielskiego dla celów biznesowych była także często podkreślana na wcześniejszych etapach nauki, poczynając od wyjaśnienia specyfiki zajęć Business English na początku kursu. 
samooceny napisanego przez siebie tekstu oraz wzajemnej oceny swoich tekstów we współpracy z innymi studentami, nie tyle pod względem językowym, co raczej pod kątem prawidłowości, skuteczności i profesjonalizmu wykonania zadania (według kryteriów podanych przez nauczyciela w postaci pytań kontrolnych). ${ }^{8}$ Warto zauważyć, że na tym etapie jedynie $10 \%$ studentów skorzystało z szansy przeredagowania swojego tekstu i oddania go nauczycielowi na kolejnych zajęciach; pozostali uznali swe prace za wystarczająco dobre. Jest to o tyle istotne, że prawie dwa razy więcej prac (ok. 20\%) zostało ocenione negatywnie, przy czym na negatywną ocenę w dużym stopniu wpłynęły błędy wykraczające poza kwestie typowo językowe.

Ankieta składała się z dwóch części. Część pierwsza, o której wypełnienie studenci zostali poproszeni zanim otrzymali poprawione i ocenione przez nauczyciela prace, zawierała dwa pytania o to, w jakim stopniu - zdaniem studentów - wykładowca Business English powinien nauczać elementów wiedzy biznesowej i profesjonalnej komunikacji w biznesie, oraz dwa pytania dotyczące tego, w jakim stopniu - zdaniem studentów - nauczyciel powinien oceniać wymienione elementy wiedzy i kompetencji. Druga część ankiety, wypełniona po omówieniu ocenionych prac, miała na celu sprawdzenie czy i w jakim stopniu studenci uznali, że ich prace zostały ocenione sprawiedliwie, tzn. czy proporcje w ocenie aspektu językowego i aspektu 'merytorycznego'/ 'profesjonalnego' były zdaniem studentów prawidłowe.

Tabela 1 przedstawia podsumowanie wyników uzyskanych w pierwszej części ankiety.

I r. II r. RAZEM

Cz. I Pytanie 1

Na kursie Business English nauczyciel powinien

A) przekazywać wiedzę biznesową (przynajmniej w ogólnym zarysie, gdy materiał językowy dotyczy konkretnego tematu biznesowego) wyjaśniając przy tym kwestie typowo językowe $\quad 45 \% \quad 47 \% \quad 46 \%$

B) nauczać terminologii biznesowej oraz przekazywać treści typowo językowe i tylko w razie potrzeby wyjaśniać trudne

do zrozumienia dla studentów treści przedmiotowe
C) przekazywać wyłącznie treści typowo językowe, z uwzględnieniem słownictwa biznesowego

Cz. I Pytanie 2

Na kursie Business English nauczyciel powinien

A) nauczać komunikacji w biznesie w języku angielskim, informując, jak prawidłowo, skutecznie i profesjonalnie wykonać zadania w danej sytuacji komunikacyjnej,

${ }^{8}$ Samoocena (self-assessment), jak również wzajemna ocena wykonanego zadania w grupie uczących się (peer assessment) są wartościowymi technikami rozwijania kompetencji językowych i ewaluacji postępów w nauce JB, stanowiącymi cenne uzupełnienie ewaluacji dokonywanej przez nauczyciela (zob. T. Dudley-Evans/ M.J. St. John 1998; B. Ligara/ W.Szupelak 2012). 
z uwzględnieniem zwrotów użytecznych w danym kontekście $\quad 61 \% \quad 66 \% \quad 63 \%$

B) nauczać komunikacji w biznesie w języku angielskim,

z uwzględnieniem zwrotów użytecznych w danej sytuacji

komunikacyjnej i reagować tylko na te zachowania

komunikacyjne studentów, które są zdecydowanie

nieprawidłowe, nieskuteczne i nieprofesjonalne

C) skupiać się na języku, z uwzględnieniem zwrotów

użytecznych w danej sytuacji komunikacyjnej

$31 \% \quad 30 \% \quad 31 \%$

$8 \% \quad 4 \% \quad 6 \%$

Cz. I Pytanie 3

Na kursie Business English nauczyciel powinien oceniać wiedzę testowaną w czasie sprawdzianów (pisemnych i ustnych)

A) zarówno pod względem językowym jak i merytorycznym,

ponieważ znajomość fachowych wyrażeń w języku

angielskim oraz treści i kontekstów związanych z tymi

wyrażeniami są ze sobą ściśle powiązane

$43 \% \quad 57 \% \quad 50 \%$

B) przede wszystkim pod względem językowym - kwestie

poprawności merytorycznej mogą zostać omówione przez

nauczyciela i studentów w ogólnej dyskusji, ale nie

powinny podlegać ocenie

C) wyłącznie pod względem językowym, ponieważ

poprawność merytoryczna pozostaje tylko produktem

ubocznym na zajęciach Business English

$48 \% \quad 43 \% \quad 45 \%$

Cz. I Pytanie 4

$\mathrm{Na}$ kursie Business English nauczyciel powinien oceniać wykonywane przez studentów zadania

A) zarówno pod względem językowym jak i merytorycznym, ponieważ stopień prawidłowości wykonania zadania, oraz skuteczność i profesjonalizm zachowania w danej sytuacji komunikacyjnej są co najmniej tak ważne jak poprawność językowa

$47 \% \quad 74 \% \quad 60 \%$

B) przede wszystkim pod względem językowym - stopień

prawidłowości wykonania zadania oraz skuteczności

i profesjonalizmu zachowania $\mathrm{w}$ danej sytuacji

komunikacyjnej mogą zostać omówione przez nauczyciela

i studentów w ogólnej dyskusji, ale nie powinny

podlegać ocenie

$43 \% \quad 26 \% \quad 35 \%$

C) wyłącznie pod względem językowym, ponieważ stopień

prawidłowości wykonania zadania oraz skuteczności

i profesjonalizmu zachowania w danej sytuacji

komunikacyjnej pozostają tylko produktem ubocznym

na zajęciach Business English

Tabela 1. Wyniki pierwszej części ankiety:

W jakim stopniu nauczyciel Business English powinien nauczać elementów wiedzy przedmiotowej i kompetencji przydatnych w komunikacji biznesowej?. Źródto: opracowanie własne. 
Jak wynika z Tabeli 1, odsetek studentów, którzy postrzegają rolę nauczyciela języka biznesu przede wszystkim przez pryzmat przekazywania wiedzy językowej i nauczania komunikacji w języku obcym (z uwzględnieniem słownictwa biznesowego i zwrotów użytecznych w danej sytuacji komunikacyjnej) jest stosunkowo niewielki (odpowiednio 10\% i 6\%). Wyraźnie wyższy odsetek studentów (odpowiednio $46 \%$ i $44 \%$ ) oczekuje od nauczyciela nie tylko nauczania terminologii biznesowej, ale również przekazywania wiedzy biznesowej potrzebnej do skutecznego przyswojenia realizowanego materiału językowego. Aż $63 \%$ respondentów jest zdania, że nauczyciel powinien informować jak prawidłowo, skutecznie i profesjonalnie komunikować się w biznesie w języku angielskim; odsetek studentów, których oczekiwania w tym zakresie ograniczają się do reakcji nauczyciela wyłącznie na te zachowania komunikacyjne, które są zdecydowanie nieprawidłowe, nieskuteczne i nieprofesjonalne $\mathrm{w}$ danej sytuacji komunikacyjnej, jest znacznie niższy (31\%). Widać również wyraźną różnicę w wyborach dokonanych przez studentów I i II roku - ci ostatni, wraz z przyrostem wiedzy biznesowej i kompetencji komunikacyjnych właściwych dla świata biznesu wydają się w coraz mniejszym stopniu oczekiwać od nauczyciela przede wszystkim nauczania języka i rozwijania ogólnej kompetencji komunikacyjnej, w większym stopniu natomiast doceniają rolę nauczyciela w budowaniu świadomości i wiedzy biznesowej (przynajmniej w pewnym zakresie) oraz w rozwijaniu umiejętności skutecznego i profesjonalnego komunikowania się w sytuacjach biznesowych.

Jeśli chodzi o oczekiwania studentów dotyczące tego, co powinien oceniać nauczyciel Business English, rola wykładowcy jako osoby oceniającej wyniki pracy studentów wyłącznie przez pryzmat języka jest postrzegana jeszcze bardziej negatywnie niż rola przekaziciela treści typowo językowych. Połowa studentów jest zdania, że nauczyciel powinien oceniać wiedzę testowaną w czasie sprawdzianów (pisemnych i ustnych) zarówno pod względem językowym jak i merytorycznym. Jeszcze wyższy odsetek studentów (60\%) oczekuje, że nauczyciel będzie uwzględniał obydwa te aspekty w ocenie wykonywania przez studentów zadań komunikacyjnych. Znamienne jest, że żaden student II roku nie zaznaczył odpowiedzi $\mathrm{C}$ w pytaniach 3 i 4, a liczba tych, którzy oczekują ze strony nauczyciela oceny wiedzy i kompetencji zarówno pod względem językowym, jak i merytorycznym przewyższa odsetek studentów I roku wyrażających taką opinię. Widać zatem wyraźnie, że studenci (szczególnie II roku) kierunków biznesowych akceptują konieczność poszerzania wiedzy biznesowej i rozwijania profesjonalnych umiejętności komunikacyjnych na zajęciach Business English; pozytywnie odnoszą się oni również do roli nauczyciela w ocenianiu nie tylko wiedzy i kompetencji językowych, ale również wiedzy merytorycznej i umiejętności profesjonalnego komunikowania się w sytuacjach biznesowych.

Celem drugiej części ankiety było sprawdzenie, czy oczekiwania studentów co do roli wykładowcy w nauczaniu oraz ocenianiu wiedzy i kompetencji merytorycznych pokrywają się z ich odczuciami już po otrzymaniu swoich autentycznych prac sprawdzonych i ocenionych przez nauczyciela. Tabela 2 przedstawia wyniki tej części badania. 
I r. II r. RAZEM

A) Uważam, że proporcje oceny poprawności językowej oraz mojej wiedzy merytorycznej, a także prawidłowości, skuteczności i profesjonalizmu wykonania zadania, są właściwe.

B) Uważam, że wykazana przeze mnie wiedza merytoryczna oraz prawidłowość, skuteczność i profesjonalizm wykonania zadania zbyt mocno zawyżyły punktację. Obiektywnie stwierdzam, że powinienem dostać niższą ocenę ze względu na błędy językowe zaznaczone przez nauczyciela.

$81 \% \quad 90 \% \quad 85 \%$

$7 \% \quad 6 \% \quad 7 \%$

C) Uważam, że moje braki w zakresie wiedzy merytorycznej oraz prawidłowości, skuteczności i profesjonalizmu wykonania zadania zbyt mocno zaniżyły punktację. Ilość zaznaczonych przez nauczyciela błędów językowych jest raczej niewielka i to powinno stanowić zdecydowanie najważniejsze kryterium oceny

Tabela 2. Wyniki drugiej części ankiety: Ocena prac pisemnych - refleksje studentów. Źródto: opracowanie własne.

Tabela 2 wyraźnie pokazuje, że stopień akceptacji wyników uzyskanych z prac pisemnych jest bardzo wysoki - aż 85\% respondentów uznało, że proporcje oceny wykazanej przez nich poprawności językowej oraz wiedzy merytorycznej, a także prawidłowości, skuteczności i profesjonalizmu wykonania zadania, są właściwe. Warto podkreślić, że odsetek ocen niedostatecznych wystawionych przez nauczyciela zdecydowanie przewyższał odsetek studentów, którzy wybrali odpowiedź C, tzn. uznali, że braki w zakresie wiedzy merytorycznej oraz prawidłowości, skuteczności i profesjonalizmu wykonania zadania zbyt mocno zaniżyły ocenę (8\%). Podobna grupa respondentów (7\%) wyraziła opinię, że uzyskana przez nich ocena jest obiektywnie zbyt wysoka, biorąc pod uwagę sporą (w odczuciu studentów) liczbę błędów typowo językowych. Opinia ta wynika prawdopodobnie z faktu, iż na wcześniejszych etapach nauki języka aspekt ten stanowił wyłączne lub zdecydowanie najważniejsze kryterium oceny prac pisemnych i studenci byli nieco zaskoczeni widząc, że kilka błędów (na przykład gramatycznych) nie zdyskwalifikowało pracy. Podobnie jak w wynikach uzyskanych w części pierwszej, odpowiedzi udzielone przez studentów II roku w drugiej część ankiety potwierdzają, że wraz z przyrostem wiedzy i doświadczenia rośnie także akceptacja dla oceny zarówno treści językowych, jak i merytorycznych.

\section{Wnioski}

Wyniki pierwszej części omówionego powyżej badania wskazują, że studenci studiów licencjackich Uniwersytetu Ekonomicznego w Katowicach w dużym stopniu akceptują uwzględnienie kryterium tzw. 'podwójnej kompetencji' w ocenie wyko- 
nywanych przez nich zadań na kursie języka angielskiego dla celów biznesowych. Prawie połowa badanych oczekuje od nauczyciela Business English przekazywania elementów wiedzy fachowej i nauczania terminologii biznesowej, a ponad $60 \%$ respondentów jest zdania, że nauczyciel powinien również nauczać skutecznej i profesjonalnej komunikacji adekwatnej dla środowiska biznesu. Jeśli chodzi o oczekiwania studentów dotyczące tego, co powinien oceniać nauczyciel Business English, połowa respondentów wyraża opinię, że nauczyciel JB powinien oceniać wiedze testowaną $\mathrm{w}$ czasie sprawdzianów (pisemnych i ustnych) zarówno pod względem językowym jak i merytorycznym. Jeszcze wyższy odsetek studentów $(60 \%)$ oczekuje, że nauczyciel będzie uwzględniał obydwa te aspekty w ocenie wykonywania przez studentów zadań komunikacyjnych.

Wyniki uzyskane w części drugiej, w której studenci mieli wyrazić swoje opinie na temat sposobu oceniania przez nauczyciela sporządzonych $\mathrm{w}$ ramach pracy domowej prac pisemnych, wyraźnie pokazuje, że stopień akceptacji dla stosowania kryterium 'podwójnej kompetencji' jest bardzo wysoki - aż 85\% respondentów uznało, że proporcje oceny wykazanej przez nich poprawności językowej oraz wiedzy merytorycznej, a także prawidłowości, skuteczności i profesjonalizmu wykonania zadania, są właściwe.

Warto podkreślić, że odpowiedzi udzielone w obu częściach ankiety przez studentów drugiego roku wskazują, że wraz z przyrostem wiedzy i doświadczenia rośnie także akceptacja dla oceny przez nauczyciela JB stopnia opanowania przez uczących się nie tylko treści i kompetencji językowych, ale również treści i kompetencji merytorycznych.

Można zatem wysnuć wniosek, że odpowiednio wykwalifikowany nauczyciel JB prowadzący kurs na studiach licencjackich powinien oceniać tzw. 'podwójną kompetencję' studentów (pod warunkiem, że kwestie merytoryczne są poruszana na zajęciach i wynikają z omawianych materiałów, a nauczyciel wyraźnie akcentuje ich wagę oraz regularnie informuje studentów, że znajomość tych treści będzie stanowiła istotne kryterium oceny zadań ewaluacyjnych). Nie można jednak pominąć faktu, że oprócz optymistycznych wyników odnoszących się do opinii studentów na temat oceny treści merytorycznych przez nauczyciela JB, omówione powyżej badanie wykazało także bardziej problematyczne aspekty rozwijania i oceniania 'podwójnej kompetencji' na specjalistycznych zajęciach językowych, potwierdzone zresztą doświadczeniem zawodowym Autorki: akceptacja studentów wyrażana dla rozwijania i oceny kompetencji merytorycznych na zajęciach języka biznesu nie zawsze przekłada się w sposób zadowalający na umiejętność zintegrowania kompetencji językowej i 'fachowej'. Brak odpowiedniej wiedzy, zawodowego doświadczenia i obycia w sytuacjach typowych dla komunikacji profesjonalnej sprawiają, że spora grupa studentów studiów licencjackich w praktyce skupia się wykonując zadania w zakresie języka biznesu prawie wyłącznie na treściach językowych, nie przywiązując należytej wagi do innych aspektów zadania. Często zawodzi również samoocena i ocena wzajemna, co bardzo wyraźnie pokazało niniejsze badanie: jak już wspomniano, tylko nieliczna grupa studentów potrafiła dostrzec na tym etapie swoje błędy (oraz błędy kolegów) i odpowiednio je skorygować. 
Kwestia lepszego doboru technik nauczania mających na celu zmniejszenie skali tych problemów pozostaje poza zakresem niniejszego opracowania. Trzeba jednak podkreślić, że bez wątpienia warto nieustannie uświadamiać studentów wkraczających dopiero w świat komunikacji biznesowej o ogromnej roli, jaką w tej komunikacji odgrywają umiejętności wykraczające poza kwestie czysto językowe i motywować ich do rozwijania tych umiejętności. Pozytywne nastawienie większości studentów do rozwijania i oceniania 'podwójnej kompetencji' na zajęciach języka biznesu, pomimo trudności $\mathrm{w}$ integrowaniu kompetencji językowej i elementów wiedzy 'fachowej' w toku wykonywanych zadań, stanowi duży potencjał, który należy wykorzystać.

\section{Bibliografia}

Angelo, T./ K.P. Cross (1993), Classroom Assessment Techniques: A Handbook for College Teachers, San Francisco.

Bargiela-Chiappini, F./ Z. Zhang (2013), Business English, (w:) B. Paltridge/ S. Starfield (red.), The Handbook of English for Specific Purposes. Chichester, 193-211.

Basturkmen, H. (2001), Developing Courses for English for Specific Purposes, Basingstoke.

Basturkmen, H. (2006), Ideas and Options in English for Specific Purposes. London.

Bhatia, V.K./ L. Anthony/ J. Noguchi (2011), ESP in the 21st Century: ESP Theory and Application Today, (w:) "Proceedings of the JACET 50th Commemorative International Convention", 1-8. (URL https:/ / www.researchgate.net/ publication/267631416_ESP_in_the_21st_Century_ESP_Theory_and_Application_Tod ay). [Pobrano 10.08.2016].

Brinton, D.M./ M.A. Snow/ M.B. Wesche (1989), Content-Based Second Language Instruction. New York.

Brinton, D.M. (2007), Content-based instruction: Reflecting on its applicability to the teaching of Korean. (URL http:/ / www.aatk.org/ www/ html/ conference2007/ pdf/ Donna \%20Brinton.pdf). [Pobrano 19.03.2012].

Canale, M./ M. Swain (1980), Theoretical Bases of Communicative Approaches to Second Language Teaching and Testing, (w:) ,Applied Linguistics” 1, 1-47.

Canale, M. (1983), From Communicative Competence to Communicative Language Pedagogy, (w:) J.C. Richards/ R.W. Schmidt (red.), Language and Communication. London, 2-27.

Cheng, A. (2015), Rethinking the Paths toward Developing ESP Practitioners' Specialized Knowledge through the Lens of Genre Analysis, (w:) „English as a Global Language Education" 1, 23-45.

Cianflone, E./ R. Coppolino (2009), English for Specific Purposes and Content Teacher Collaboration: Report on a Pilot Project, (w:) „English for Specific Purposes" 8(3), 1-8. (URL http:/ / www.esp-world.info/ Articles_24/ Cianflone \% 20\& \%20 Coppolino.pdf). [Pobrano 19.03. 2012]. 
Donna, S. (2000), Teach Business English, Cambridge.

Douglas, D. (2000), Assessing English for Specific Purposes, Cambridge.

Douglas, D. (2013), ESP and Assessment, (w:) B. Paltridge/ S. Starfield (red.), The Handbook of English for Specific Purposes. Chichester, 367-383.

Douglas, D./ R.K. Myers (2000), Assessing the Communication Skills of Veterinary Students: Whose Criteria?, (w:) A. Kunnan (red.), Fairness in validation in language assessment. Selected papers from the19th Language Testing Research Colloquium. Studies in Language Testing 9. Cambridge, 60-81.

Dudley-Evans, T./ M.J. St John (1998), Developments in ESP. A multi-disciplinary approach. Cambridge.

Dudley-Evans, T. (2000), Genre analysis: a key to a theory of ESP?, (w:) „IBERICA” 2, 3-11.

Ellis, M./ C. Johnson (2000), Teaching Business English. Oxford.

Fergusson, G. (1997), Teacher Education and LSP: The Role of Specialized Knowledge, (w:) R. Howard/ G. Brown (red.), Teacher Education for Languages for Specific Purposes. Clevedon, 80-89.

Frendo, E. (2005), How to Teach Business English. Harlow.

Gajewska, E./ M. Sendur (2015), Ocenianie w nauczaniu języków obcych zorientowanym na cele ogólne a ocenianie $w$ nauczaniu zorientowanym na cele zawodowe, (w:) „Języki Obce w Szkole” 3/ 2015, 49-53.

Gajewska, E./ M. Sowa (2014), LSP, FOS, Fachsprache... Dydaktyka języków specjalistycznych. Lublin.

Grabe, W./ F.L. Stoller (1997), Content-Based Instruction: Research Foundations, (w:) M.A. Snow/ D. M. Brinton (red.), The Content-Based Classroom: Perspectives on Integrating Language and Content. New York, 5-21.

Grucza, S. (2006), Komunikacja specjalistyczna a idiokontekst specjalistyczny i konsytuacja specjalistyczna, (w:) A. Wołodźko-Butkiewicz/ W. Zmarzer (red.), Glottodydaktyka i jej konteksty interkulturowe, Studia Rossica XVIII. Warszawa, 209-223.

Grucza, S. (2007), Glottodydaktyka specjalistyczna. Część 1. Założenia lingwistyczne dydaktyki języków specjalistycznych, (w:) „Przegląd glottodydaktyczny” 23, $7-20$.

Grucza, S. (2008), Lingwistyka języków specjalistycznych, Warszawa.

Grucza, S. (2009), Kategoryzacja języków (specjalistycznych) w świetle antropologicznej teorii języków ludzkich, (w:) „Komunikacja specjalistyczna” 2, 15-30.

Grygiel, M. (2015), Business English from a Linguistic Perspective, (w:) „English for Specific Purposes World" Special Issue 1, vol. 16, 1-12.

Hutchinson, T./ A. Waters (1987), English for Specific Purposes. A LearningCentred Approach. Cambridge.

Jacoby, S./ T. McNamara (1999). Locating Competence, (w:) „English for Specific Purposes" 1, 213-241.

Kasper, L. F. (1997), The Impact of Content-based Instructional Programs on the Academic Progress of ESL Students, (w:) „English for Specific Purposes” 16, 309-320. 
Kavaliauskiene, G. (2004), Research into the Integration of Content-Based Instruction into the ESP Classroom, (w:) ,Journal of Language and Learning” 2(1), 112.

Komorowska, H. (2005), Metodyka nauczania języków obcych. Warszawa.

Kubiak, B. (2002), Pojęcie języka specjalistycznego, (w:) „Języki Obce w Szkole” 5/ 2002, 6-11.

Kubiak, B. (2005), Koncepcje nauczania języka specjalistycznego, (w:) „Języki Obce w Szkole" 5/ 2005, 19-24.

Kubiak, B. (2006), Typologia nauczania języka specjalistycznego, (w:) „Języki Obce w Szkole" 2/ 2006, 25-30.

Ligara, B./ W. Szupelak (2012), Lingwistyka i glottodydaktyka języków specjalistycznych na przykładzie języka biznesu. Podejście porównawcze. Kraków.

Lukszyn, J. (2005) Język specjalistyczny, (w:) J. Lukszyn (red.), Języki specjalistyczne. Słownik terminologii przedmiotowej. Warszawa.

Lynch, B.K. (2003), Language Assessment and Programme Evaluation. Edinburgh.

Łompieś, J. (2008), Czym jest Business Communication?, (w:) M. Łukasik (red.), Debiuty naukowe II. Terminologia - translatoryka - terminografia. Warszawa, 11-25.

Mamet, P. (2002), Relacja pomiędzy kompetencja językowa a kompetencja merytoryczna na przykładzie języka biznesu, (w:) J. Lewandowski (red.), Problemy techno lingwistyki. Warszawa, 141-151.

Master, P. (1997), Content-Based Instruction vs. ESP, (w:) „TESOL Matters” 7(6), 10.

Met, M. (1999), Content-Based Instruction: Defining Terms, Making Decisions. (URL http:/ / www.carla.umn.edu/ cobaltt/ modules/ principles/ decisions.html). [Pobrano 11.11.2011].

Myers, G.A. (1992), Textbooks and the Sociology of Scientific Knowledge, (w:) „English for Specific Purposes” 11, 3-17.

Nelson, M. (2000). A Corpus-Based Study of the Lexis of Business English and Business English Teaching Materials.

(URL http:/ / users.utu.fi/ micnel/ thesis.html). [Pobrano 23.02.2012].

Pickett, D. (1986), Business English: Falling between Two Stools, (w:) „Colmon” 26, 16-21.

Pierini, F. (2014), Definition and Main Features of Business English with a Special Regard to Differences with the Language of Economics, (w:) „ESP across Cultures" 11, 109-119.

Richards, J.C./ T.S. Rodgers (2002), Approaches and Methods in Language Teaching (wyd. 2). Cambridge.

Strevens, P. (1973), Technical, Technological and Scientific English, (w:) "ELT Journal" 27, 223-234.

Strevens, P. (1977), Special-Purposes Language Learning, (w:) „Language Teaching and Linguistics, Abstracts" 10, 154-163.

Sobkowiak, P. (2008), Issues in ESP: Designing a Model for Teaching English for Business Purposes. Poznań. 
Stryker, S.B./ B.L. Leaver (1997), Content-Based Instruction in Foreign Language Education: Models and Methods. Washington D.C.

Szerszeń, P. (2015), Dydaktyka "języka ekonomii" (I). Kilka uwag o lingwistycznych uwarunkowaniach dydaktyki "języka ekonomii", (w:) „Lingwistyka Stosowana/ Applied Linguistics/ Angewandte Linguistik" 13, 77-85.

White, R./ M. Martin/ M. Stimson/ R. Hodge (1991), Management in English Language Teaching. Cambridge.

Willis, J. (1996), A Framework for Task-based Learning. Harlow.

Zhao, J. (2002), Wirtschaftsdeutsch als Fremdsprache. Ein didaktisches Modell. Tübingen.

Zhu, W. (2008), A New Perspective of the Concept and Develoment Trend of Business English in Higher Education Institutions, (w:) „Journal of International Education Studies" 1 (2), 28-31. 